NBER WORKING PAPER SERIES

\title{
DISPLACING THE FAMILY: UNION \\ ARMY PENSIONS AND ELDERLY \\ LIVING ARRANGEMENTS
}

Dora L. Costa

Working Paper 5429

NATIONAL BUREAU OF ECONOMIC RESEARCH

1050 Massachusetts Avenue

Cambridge, MA 02138

January 1996

I have benefited from the comments of Matthew Kahn, Chulhee Lee, Peter Temin, seminar participants at Vanderbilt University, and conference participants at the 1995 Social Science History Association Meetings. I gratefully acknowledge the support of a NIA Aging Fellowship at the National Bureau of Economic Research and of NIH grants AG12651-01A1 and AG1012005. This paper is part of NBER's research programs in Aging, and the Development of the American Economy. Any opinions expressed are those of the author and not those of the National Bureau of Economic Research.

(C) 1996 by Dora L. Costa. All rights reserved. Short sections of text, not to exceed two paragraphs, may be quoted without explicit permission provided that full credit, including () notice, is given to the source. 


\title{
DISPLACING THE FAMILY: UNION \\ ARMY PENSIONS AND ELDERLY \\ LIVING ARRANGEMENTS
}

\begin{abstract}
I argue that the trend toward single households among retired men 65 years of age or older has been ongoing since 1880 . When coresidence is measured by the percentage of elderly men living in the households of their children or other relatives, fully 57 percent of the decline in coresidence among elderly retired men from 1880 to 1990 occurred between 1880 and 1940 . This trend has been disguised in more aggregated statistics by the relatively low retirement rates that prevailed in the past and by the unchanging coresidence levels of labor force participants.

I investigate the factors that fostered this rise in separate living quarters for the aged by examining the determinants of living arrangements in 1910 among retired veterans receiving Union Army pensions. I find that Union Army pensions exerted a sizable, negative impact on the coresidence rates of the retired, implying that increases in income have always been associated with an increased demand for the privacy and autonomy provided by separate living arrangements. My findings imply that prior to 1940 rising incomes were the most important factor enabling the elderly to live alone. After 1940, increases in the attractiveness of independent living may have played a role.
\end{abstract}

Dora L. Costa

Department of Economics, E52-251A Massachusetts Institute of Technology

50 Memorial Drive

Cambridge, MA 02139

and NBER 


\section{Introduction}

The trend toward single households among retired men 65 years of age or older has been ongoing since 1880. Fully 57 percent of the decline in coresidence among elderly, retired men from 1880 to 1990 , as measured by the percentage of elderly men living in the households of their children or other relatives, occurred between 1880 and 1940. Many economists, demographers, and historians have been unaware of the trend prior to 1940 because it has been disguised in more aggregated statistics by the relatively low retirement rates that prevailed in the past and by the unchanging coresidence patterns of labor force participants. This paper will both examine the longterm trend in coresidence patterns among elderly males and assess explanations for the trend.

Several factors are likely contributers to the rise in independent, elderly households from 1880 to the present. The Social Security old age insurance and old age assistance programs were instituted in 1935 and grew steadily after $1950 .^{1}$ Private pensions expanded rapidly after the Second World War. Income has been rising since 1880. Declines in fertility have increased the ratio of aged parents to adult children. ${ }^{2}$ Improvements in the health of the elderly and in household technology may now enable the elderly to live alone. The leisurely retirement lifestyle that has become the postwar ideal is often only possible by resettlement to another community with a better climate or recreational amenities. ${ }^{3}$ Finally, changing social values may explain part of the trend since 1880 (Smith 1979; Ruggles 1987). In the past, children may have been more willing to welcome their aged parents into their own homes and more parents may have preferred to live with their children.

Most work on the subject has used post-1950s cross-sectional data, however the appli-

\footnotetext{
${ }^{1}$ See Michael, Fuchs, and Scott (1980) and Schorr (1960) for the impact of Social Security benefits on elderly living arrangements.

${ }^{2}$ See Wolf (1994) for a review of the literature on living arrangements and the availability of kin.

${ }^{3}$ See Longino (1990) for a review of the literature on elderly migration.
} 
cability of cross-sectional estimates to periods outside the sample range is questionable. Although elderly living arrangements have been studied using early twentieth century cross-sectional data (Smith 1979; Ruggles 1987), research has been stymied by the absence of information on the income of the aged. It has not been possible to analyze the impact of rising incomes on the growth in independent, elderly households in the first half of the twentieth century. To understand the factors that fostered the rise in separate living quarters for the aged, I investigate the determinants of living arrangements in 1910 among white, retired Union Army veterans receiving Union Army pensions.

Union Army pensions were available to veterans regardless of their labor force participation status or their own or their children's wealth or earnings. Because of the rules of the program, much of the variation in pension amount was unrelated to individual characteristics. I therefore can use pension income as a test of revealed preference to determine whether coresidence or independent living was preferred by retired, elderly men. My findings therefore have implications for the relative importance of increasing income, including Social Security, in explaining the rise of elderly single households. My findings also have implications for secular changes in the quality of life of the elderly. If rising incomes have given the elderly greater control over their own living arrangements, then elderly quality of life has improved markedly.

The Union Army records reveal the experiences of the old at a time when aging was just emerging as a public issue. The 1910 Massachusetts Commission on Pensions and Annuities concluded that pensions would have a disintegrating effect on the family (cited in Epstein 1928: 227). In contrast, advocates of state-provided pensions decried the burden that dependence imposed on young and old alike and argued that both the elderly and their children would be happier if they could afford to live in separate dwellings (Epstein 1928: 144-148). Social Security is widely regarded as having permitted just such a separation. I will examine the impact on living arrangements of the first major pension program in the United States prior to most private pensions 
and Social Security. This program was cited by some proponents of state-provided pensions as building up the family because children would be more likely to find a place in their own homes for parents who could partially pay their own way. ${ }^{4}$ First, however, I will establish that the trend towards elderly, single households has been ongoing since 1880 .

\section{Trends in Elderly Living Arrangements}

Living arrangements have been measured in a variety of ways. One useful indicator of household authority and of dependence is whether elderly males were household heads. Although there has been little change from 1880 to 1940 in the probability of all men 65 years of age heading their own households, there has been a steady increase since 1880 in the probability of retired men heading their own households (see Table 1). In fact, 48 percent of the increase in retired men heading their own households occurred between 1880 and $1940 .^{5}$

Another indicator of living arrangements is the percentage of elderly men living in extended families, here defined as households where a family member other than the spouse was present. For the most part, these are households in which the adult children are present. The decline in the percentage of men at least 65 years old living in extended families from 1880 to 1940 is evident among both the retired and those still in the labor force. However, part of the decline may be due not to the elderly being less likely to live in their relatives' households, but to declines in the age at which children leave home or in declines in the propensity of the elderly to take in relatives. Table 2 therefore subdivides the data even further.

Table 2 shows that among the retired the decline in the percentage living in extended

\footnotetext{
${ }^{4}$ Dissenting opinion in the 1910 Report of the Massachusetts Commission on Pensions and Annuities. Cited in Epstein (1928: 228).

${ }^{5}$ The 1950 decline probably arose from World War II housing shortages.
} 
Table 1: Percent of Noninstitutionalized Men 65 or Older Who were Household Heads and Who Did Not Live in Extended Families, by Retirement Status

\begin{tabular}{crrr|rrr}
\multicolumn{4}{c}{ \% Household Heads } & \multicolumn{3}{c}{ \% Not Living in } \\
Extended Family
\end{tabular}

Note. Estimated from the integrated public use census series (Ruggles and Sobeck 1995). Living in an extended family is defined as living in a household in which family members other than the wife are present. The number of retired was calculated using the concept of gainful employment prior to 1940 and the concept of current employment in 1940 and later. The basic pattern remains unchanged if the institutionalized are included. 
Table 2: Percent Household Heads and Percent Living in an Extended Family Among Noninstitutionalized Men 65 or Older Household, by Retirement Status

\begin{tabular}{|c|c|c|c|c|c|c|c|c|c|c|c|c|}
\hline \multirow[b]{2}{*}{ year } & \multicolumn{3}{|c|}{$\begin{array}{l}\% \text { Household Heads } \\
\text { and Living in } \\
\text { Extended Family } \\
(1)\end{array}$} & \multicolumn{3}{|c|}{$\begin{array}{l}\text { \% Household Heads } \\
\text { and Not Living in } \\
\text { Extended Family } \\
(2)\end{array}$} & \multicolumn{3}{|c|}{$\begin{array}{c}\text { \% Not Household Heads } \\
\text { and Living in } \\
\text { Extended Family } \\
\text { (3) }\end{array}$} & \multicolumn{3}{|c|}{$\begin{array}{l}\text { \% Not Household Heads } \\
\text { and Not Living in } \\
\text { Extended Family } \\
\text { (4) }\end{array}$} \\
\hline & total & retired & $\begin{array}{c}\text { not } \\
\text { retired }\end{array}$ & total & retired & $\begin{array}{c}\text { not } \\
\text { retired }\end{array}$ & total & retired & $\begin{array}{c}\text { not } \\
\text { retired }\end{array}$ & total & retired & $\begin{array}{c}\text { not } \\
\text { retired }\end{array}$ \\
\hline 1880 & 54.7 & 31.7 & 61.7 & 24.0 & 20.4 & 25.2 & 16.4 & 41.3 & 8.8 & 4.9 & 6.6 & 4.3 \\
\hline 1900 & 51.2 & 34.1 & 77.4 & 24.6 & 20.9 & 26.5 & 17.5 & 36.3 & 7.8 & 6.7 & 8.7 & 5.7 \\
\hline 1910 & 47.4 & 34.7 & 55.4 & 28.7 & 26.9 & 29.8 & 17.3 & 31.6 & 8.2 & 6.7 & 6.8 & 6.6 \\
\hline 1920 & 42.7 & 33.3 & 50.1 & 33.2 & 31.1 & 34.8 & 18.0 & 29.8 & 8.5 & 6.2 & 5.7 & 6.7 \\
\hline 1940 & 38.5 & 31.7 & 47.2 & 39.0 & 37.9 & 40.3 & 15.4 & 22.5 & 6.3 & 7.2 & 7.9 & 6.2 \\
\hline 1950 & 39.7 & 33.3 & 48.4 & 31.9 & 29.6 & 35.0 & 22.1 & 30.3 & 11.1 & 6.3 & 6.8 & 5.6 \\
\hline 1960 & 23.3 & 21.6 & 26.7 & 62.5 & 61.3 & 65.2 & 10.5 & 13.2 & 4.8 & 3.7 & 4.0 & 3.2 \\
\hline 1970 & 18.0 & 16.5 & 22.4 & 72.4 & 72.5 & 71.9 & 7.2 & 8.5 & 3.7 & 2.4 & 2.5 & 2.1 \\
\hline 1980 & 15.3 & 14.2 & 20.0 & 74.4 & 74.9 & 72.5 & 6.0 & 6.5 & 3.8 & 4.3 & 4.5 & 3.7 \\
\hline 1990 & 13.5 & 12.3 & 18.7 & 76.5 & 77.4 & 72.6 & 4.0 & 4.3 & 2.7 & 6.1 & 6.1 & 6.0 \\
\hline
\end{tabular}

Note. See Table 1 for sources.

families fell from 1880 to 1940 only among those who were no longer household heads. Among those who were household heads, the percentage has fallen only since 1950 (see columns 1 and 3). Table 2 also shows that the decreased probability of retired men not heading their own households arose from sharp declines in the percentage of older, retired men living in extended families which they did not head (see columns 3 and 4). Forty-one percent of older, retired men were coresiding in extended family households in 1880 , but only 23 percent were in 1940,13 percent in 1970 , and 5 percent in 1990 . Thus fully 57 percent of the 1880 to 1990 decline occurred between 1880 and 1940.

Differences by retirement status in the percentage of elderly men coresiding with extended family members were much larger at the beginning of the twentieth century than at the century's end (see Table 2), suggesting that in the past the family was far more important to retirement strategies than it is today. In the past, only men who worked retained their independence. Those who did not either remained in the same household, relinquishing their position of authority 
to their children, or moved into the household of their children. The 1919 Ohio Commission on Health Insurance and Old Age Pensions estimated that in Hamilton and Cincinnati 15 to 25 percent of people over age 50 were dependent upon relatives or friends (cited in Epstein 1928: $50) .^{6}$

Dependence upon the family was necessary because the only other source of retirement income was savings, at a time when incomes were low. A large segment of the population had little in the form of savings. Surveys of the non-dependent aged in the northeast in the mid-1920s suggest that 20 percent had assets and property worth less than $\$ 850$ in 1917 dollars (Gratton and Rotondo 1991), a sum that could cover about one year's worth of a retired couple's expenditures. ${ }^{7}$ Those who had accumulated more assets could not be assured that these were enough because either spouse might live longer than expected. The lack of adequate savings was a problem that was widely recognized by contemporaries. In his decision upholding the constitutionality of Social Security, Cardozo argued that most industrial workers reached old age with few resources. ${ }^{8}$ Union Army veterans were one group in early twentieth century society that was less dependent on their family and on their own savings for support. At a time when private pensions were rare and state old age assistance programs had not yet been established, Union Army veterans were eligible for an extremely generous pension. By 1910, 90 percent of Union Army veterans were collecting a pension whose average value was $\$ 172$, or 33 percent of yearly income. ${ }^{9}$ The

\footnotetext{
${ }^{6}$ The fraction was probably lower among men.

${ }^{7}$ The median household did fairly well. Gratton and Rotondo (1991) estimate that middle and upper working class families in 1917-1919 that did not suffer severe misfortune could expect to accrue between $\$ 2,500$ and $\$ 5,000$ in assets by the time the head of the household reached his mid-60s. Using Lee's (1995) estimate of $\$ 789$ as the needs of an elderly couple in 1917-1919, these surpluses would provide 3 to 6 years of retirement income for an elderly couple. Lee (1995) calculates that men aged 20 could expect to spend less than 5 years in retirement.

${ }^{8}$ Helvering vs. Davis, 1937.

${ }^{9}$ Calculated from Glasson (1918a) and Series Y 957-970 and Series D 722-727 in US Bureau of the Census (1975).
} 
relative generosity of the Union Army pension was therefore comparable to that of Social Security retirement benefits which in 1991 represented 31 percent of average annual pay. ${ }^{10}$

\section{Civil War Pensions and Union Army Records}

The magnitude of Union Army pensions suggests that they affected retired veterans' living arrangements. Pension income is likely to have enabled veterans either to live on their own or with their children and thus to pick their preferred residence option. Children who took aged pensioners into their homes may have received financial transfers as well as the knowledge that their parents were being taken care of, even though they may had to listen to interminable Civil War stories. Pensioners living with family members may have received free market goods and services that might otherwise have had to be provided by the pensioners themselves, their spouses, or hired help. They would also have been near their grandchildren. But, elderly retirees who chose to live with their children may have been more constrained in their choice of consumption bundles. For example, they may not have been able to increase the size of their living space and therefore guarantee themselves a certain amount of privacy.

Although elderly living arrangements are the outcome of a joint decision between adult children and their aged parents or relatives, I can only observe the veteran's decision and therefore treat the number of children as an exogenous determinant of coresidence. I subdivide the veteran's decision into two stages. The veteran first determines the best bundle of goods and household services that he can obtain under either living arrangement given his income. Although his income does not depend upon the coresidence decision, the prices that he faces for market goods and household services such as meal preparation and personal care will vary. For some goods, he

\footnotetext{
${ }^{10}$ Calculated from Series No. 583 and 663 in US Bureau of the Census (1994: 377, 428).
} 
may face an infinite price under the coresidence option, because he will have lost some degree of autonomy in his choice of goods. Utility when independent of family members can therefore be written as $U_{i}\left(C_{i}^{*} ; Z\right)$ and utility when coresiding with family members as $U_{d}\left(C_{d}^{*} ; Z\right)$, where $C^{*}$ is the consumption bundle that is chosen and $Z$ is a vector of demographic variables and of utility shifters such as age and ethnicity. If $U_{i}\left(C_{i}^{*} ; Z\right) \geq U_{d}\left(C_{d}^{*} ; Z\right)$, the veteran will maintain an independent household. Transforming the utility functions into indirect utility functions, the veteran will maintain an independent household if $V_{i}\left(p_{i}, y ; Z\right) \geq V_{d}\left(p_{d}, y ; Z\right)$, where $p_{i}$ is the price of the bundle when independent, $p_{d}$ is the price of the bundle when dependent, and $y$ is income. Therefore, if the indirect utility functions are assumed to be linear in their arguments, the utility maximizing individual evaluates the decision function,

$$
I^{*}=V_{i}\left(p_{i}, y ; Z\right)-V_{d}\left(p_{d}, y ; Z\right)
$$

I can examine the outcome of the veteran's utility evaluation because of a unique data set based upon Union Army pension records. Because this data set has not yet neen widely used, I devote the remainder of this section to a discussion of the data.

Union Army pension records begin in 1862 when Congress established the basic system of pension laws, known as the General Law pension system, to provide pensions to both regular and volunteer recruits who were disabled as a direct result of military service. ${ }^{11}$ The dollar amount received depended upon degree of disability, where disability was determined by the applicant's capacity to perform manual labor. Under later reinterpretations the total disability standard soon meant incapacity to perform even lighter types of manual labor. In fact, men judged disabled continued to labor in physically demanding, manual occupations. Inability to perform

\footnotetext{
${ }^{11}$ See Glasson (1918a) for a history of the Union Army pension program.
} 
manual labor remained the standard in this and all subsequent laws, regardless of the wealth of the individual or his ability to earn a living by other than manual means. Withdrawal from the labor force was not a necessary prerequisite for the receipt of a pension. If the claimant had lesser disabilities then he received an amount proportionate to his disabilities. Application was through a pension attorney. A board of three local doctors, employed by the Pension Bureau and following guidelines established by the Bureau, determined the degree of disability.

The Act of June 27,1890 marked the beginning of a universal disability program for Union veterans. The new law, according to the veterans' lobby, would "place upon the rolls all survivors of the war whose conditions of health are not practically perfect."12 In fact, within a year of the act's passage, the number of pensioners on the rolls more than doubled and by 1900 close to 85 percent of all Union Army veterans were on the rolls. ${ }^{13}$ Any disability now entitled a veteran to a pension ranging from $\$ 6$ to $\$ 12$ per month. However, an applicant who could trace his disability to wartime service received substantially more for the same disability than his counterpart who could not.

Old age was first recognized by statute law as sufficient cause to qualify for a pension with the passage of the Act of February 6, 1907. ${ }^{14}$ Any veteran who had served ninety days or more could receive a pension of $\$ 12$ if he was $62-69$, one of $\$ 15$ if he was $70-74$, and one of $\$ 20$ if he was 75 years or older. By 1910, ninety percent of all Union veterans were on the rolls, 64 percent of them were collecting a pension under the 1907 law, 22 percent under the General Law, and 14 percent under the 1890 law. ${ }^{15}$ Although this act did not have a substantial impact on the

\footnotetext{
${ }^{12}$ Quoted in Glasson (1918a).

${ }^{13}$ Deserters and men who had served less than ninety days were not eligible.

${ }^{14}$ The Pension Bureau already had authorization to grant disability pensions based on the age of the veteran from an executive order issued in 1904.

${ }^{15}$ Estimated from U.S. Bureau of Pensions (1910).
} 
total number of pensioners, it caused a noticable increase in government expenditures, because many veterans switched from the 1890 law to the 1907 law (Glasson 1918a: 234). In the sample used in this research, two-thirds of the men under the 1890 law and one third of the men under the General Law switched to the 1907 law between 1900 and 1910 . Fewer of the men under the General Law switched because most men who could successfully claim that their disabilities were related to the war received a larger pension under the General Law system. Because the prevalence of chronic conditions rose with age and because few men after age 62 could not claim some kind of disability, pension amount was effectively a function of age and of whether the retiree could trace his disabilities to the war (see Table 3). Although ability to trace ill health to the war depended upon the veteran's health status before he entered the service and whether he had been discharged from the service for disability, more importantly it depended upon the medical theories of the time. The primary characteristic that therefore needs to be controlled for to identify a pension effect is age.

The Union Army pension program generated copious records. Pension applications included rejections, retrospective information, and all applications for increases. Applications for increases could be filed at any time. In the sample studied here, each veteran filed an average of 14 applications prior to 1910. Although information on pension amount is not available for all men in the Union Army records even though all men were collecting pensions by 1910 , tests indicated that the absence of pension information is determined by random factors. These men can therefore be excluded from the subsequent regression analysis.

The Union Army records used in this research represent a 12 percent sample of a larger project that is still underway (see Fogel et al. 1991 for details) and consist of men in 45 Ohio companies linked from their army records to their pension records, including the successive medical reports of the examining surgeons of the Pension Bureau, and to the 1900 and 1910 censuses. One thousand and thirteen men were linked to the 1900 and 1910 censuses out of 1,308 
Table 3: Monthly Pension Means and Percentiles by Age, Health Status, and Law

\begin{tabular}{lrrrrrr}
\hline \hline & \multicolumn{6}{c}{ Percentile } \\
& Mean & 10 & 25 & 50 & 75 & 90 \\
\hline \hline All veterans & 16.5 & 12 & 12 & 15 & 20 & 24 \\
General Law & 22.3 & 14 & 17 & 24 & 24 & 30 \\
1890 Law & 11.7 & 12 & 12 & 12 & 12 & 12 \\
1907 Law & 14.5 & 12 & 12 & 15 & 15 & 20 \\
Good health & 16.3 & 12 & 12 & 15 & 20 & 24 \\
Poor health & 16.9 & 12 & 12 & 15 & 20 & 24 \\
Age $<70$ & 15.0 & 12 & 12 & 12 & 17 & 24 \\
Age $\geq 70$ & 18.8 & 15 & 15 & 17 & 20 & 24 \\
Age $<70$ and & & & & & & \\
General Law & 21.3 & 14 & 17 & 17 & 24 & 30 \\
1890 Law & 11.7 & 12 & 12 & 12 & 12 & 12 \\
1907 Law & 12.2 & 12 & 12 & 12 & 12 & 12 \\
$\quad$ & & & & & & \\
Age $\geq 70$ and & & & & & & \\
General Law & 23.9 & 17 & 17 & 24 & 30 & 30 \\
1890 Law & 11.5 & 10 & 12 & 12 & 12 & 12 \\
1907 Law & 16.9 & 15 & 15 & 15 & 20 & 20 \\
\hline \hline
\end{tabular}

Note. Calculated from the data later used in estimation. The use of a health variables based upon the ratings of the examining surgeons also showed that the relation between health status and pension amount was weak. 
at risk to be found. Among the information that these censuses and pension records provide is occupation, which was classified as 1) farmer, 2) professional or proprietor, 3) artisan, and 4) semi-skilled or unskilled laborer, including farm laborer. Wages, income, and wealth are not explicitly reported, but there is occupational information that makes it possible to estimate the income categories into which pension applicants belonged.

An examining surgeons' report is available for 73 percent of these men and these provide many health variables. The health variable that is used in estimation is a dummy equal to one if the veteran's Body Mass Index (BMI) placed him at high mortality risk or if his sight or hearing were severely impaired. ${ }^{16}$ Men without surgeons' certificates were not randomly selected. They were either men whose illness was so severe and so well established that they did not need regular exams or men who received pensions on the basis of age alone and hence did not need an exam. Therefore both men with and without surgeons' certificates are used in the regression estimates and a dummy variable indicator is used to indicate the absence of health information.

Although sixty percent of the men in this sample lived in Ohio in 1910 , the sample resembles a national one of Union Army veterans in terms of retirement status and propensity to be a household head. It resembles a national sample of the entire Civil War cohort in terms of other observable characteristics such as marital status, property ownership, and illiteracy. ${ }^{17}$ The sample contains a larger proportion of men who are rural, native-born, and farmers, but there is enough variation in the sample to effectively control for the impact of these characteristics. The sample is representative of the northern population in terms of older age mortality and wealth prior to enlistment. ${ }^{18}$

\footnotetext{
${ }^{16} \mathrm{BMI}$ is weight in kilograms divided by height in meters squared. The excessively obese and the excessively lean face a greater mortality risk (Costa 1993; Waaler 1984). The dummy variable is equal to one if BMI was below 20 or above 28.

${ }^{17}$ Calculated from the 1910 Public Use Sample (Ruggles and Sobeck 1995).

${ }^{18}$ Lifetables were constructed for men found in both censuses and compared with mortality schedules for states
} 
Table 4: Comparison of Percent Household Head or Percent Not Living in Extended Family, by Retirement Status, Between Union Army Sample and Random Samples of White Veterans and Non-veterans Aged 60-87, 1910

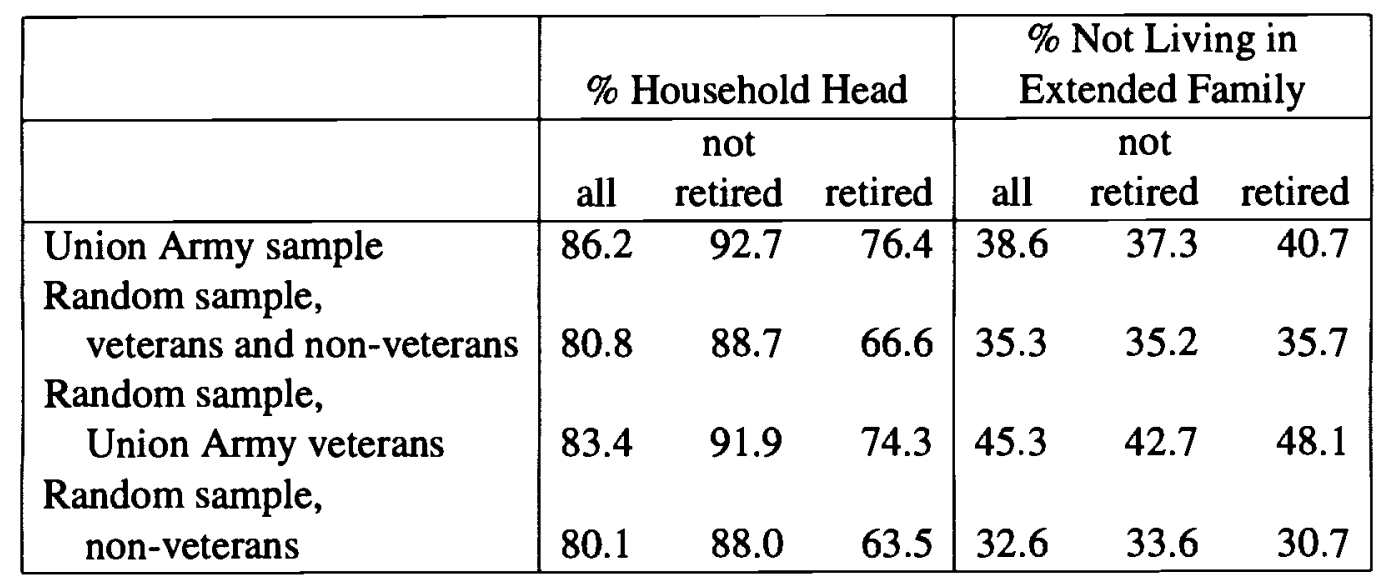

Note. The random sample was drawn from the integrated public use sample of the 1910 census (Ruggles and Sobeck 1995) and was restricted to white, noninstitutionalized men who were either born in a Union state or who, if foreign-born, immigrated prior to the Civil War. Veterans and non-veterans are identified in the sample. The random sample was reweighted to have the same geographic distribution as the Union Army sample. Living in an extended family is defined as living in a household in which family members other than the wife are present.

Tables 4 and 5 suggest that Union Army pensions determined elderly living arrangements. Seventy-six percent of retired men in the Union Army sample and 74 percent in the random sample of Union Army veterans were household heads in 1910. But, only 64 percent of retired non-veterans were household heads. The percentage of retired Union Army veterans living with no family members other than their wives was 41 percent in the Union Army sample and 48 percent in the random sample. In contrast, 31 percent of retired non-veterans in the random sample were living with no family members other than their wives. Whether children remained in a household headed by their elderly parents does not appear to depend upon veteran status

that kept death registration records. The two life tables were similar. Also, the distribution of causes of death of veterans who died circa 1910 and were in the pension records is not significantly different from the distribution of causes of death reported by the death registration states. Recruits' households were neither disproportionately rich nor poor in 1860 (Fogel et al. 1991). 
Table 5: Comparison of Percent Household Head and Percent Not Living in Extended Family, by Retirement Status, Between Union Army Sample and Random Samples of White Veterans and Non-veterans Aged 60-87, 1910

\begin{tabular}{|c|c|c|c|c|c|c|c|c|c|c|c|c|}
\hline & \multicolumn{3}{|c|}{$\begin{array}{l}\text { \% Household Head } \\
\text { and Living in } \\
\text { Extended Family }\end{array}$} & \multicolumn{3}{|c|}{$\begin{array}{l}\text { \% Not Household } \\
\text { Head and Living } \\
\text { in Extended Family }\end{array}$} & \multicolumn{3}{|c|}{$\begin{array}{l}\text { \% Household Head } \\
\text { and Not Living in } \\
\text { Extended Family }\end{array}$} & \multicolumn{3}{|c|}{$\begin{array}{l}\text { \% Not Household } \\
\text { Head and Not Living } \\
\text { in Extended Family }\end{array}$} \\
\hline & \multicolumn{3}{|c|}{ retired } & & \multicolumn{2}{|c|}{ retired } & \multicolumn{3}{|c|}{ retired } & \multicolumn{3}{|c|}{ retired } \\
\hline & all & no & yes & all & no & yes & all & no & yes & all & no & yes \\
\hline Union Army sample & 50.0 & 57.7 & 38.3 & 11.4 & 5.2 & 20.0 & 36.2 & 34.9 & 38.1 & 2.4 & 2.2 & 3.6 \\
\hline $\begin{array}{l}\text { Random sample, } \\
\text { veterans and non-veterans }\end{array}$ & 50.6 & 57.9 & 37.5 & 14.0 & 6.9 & 26.8 & 30.2 & 30.8 & 29.1 & 5.2 & 4.4 & 6.6 \\
\hline $\begin{array}{l}\text { Random sample, } \\
\text { Union Army veterans }\end{array}$ & 45.2 & 51.8 & 38.1 & 9.5 & 5.5 & 13.8 & 38.2 & 40.1 & 36.2 & 7.1 & 2.6 & 11.8 \\
\hline $\begin{array}{l}\text { Random sample, } \\
\text { non-veterans }\end{array}$ & 52.1 & 59.2 & 37.3 & 15.3 & 7.2 & 32.0 & 28.0 & 28.9 & 26.1 & 4.7 & 4.7 & 4.5 \\
\hline
\end{tabular}

Note. See Table 4 for sources. Living in an extended family is defined as living in a household in which family members other than the wife are present.

(see Table 5). But, Table 5 suggests that there were large differences by veteran status in the percentage of older men who were household heads and did not live in extended families and in the percentage of older men who were not household heads and lived in extended families. Thirty-eight percent of retired veterans in the Union Army sample and 36 percent of retired veterans in the random sample headed families consisting only of the elderly couple. Only 26 percent of retired non-veterans did so. Twenty percent of retired veterans in the Union Army sample and 14 percent in the random sample lived with a relative who was the household head. In contrast, 32 percent of retired non-veterans in the random sample did so. ${ }^{19}$

Although both Tables 4 and 5 are suggestive, they are inconclusive. Veterans are a selected sample. Lower morbidity rates or higher incomes among veterans may have decreased their probability of living in their relatives' households relative to that of non-veterans. Therefore, I

\footnotetext{
${ }^{19}$ The percentage of men who were not household heads and lived with extended family members was greater in the Union Army sample than in the random sample of Union Army veterans, perhaps because residing with non-relatives was not an option in rural areas.
} 
compare living arrangements among retired veterans controlling for characteristics such as health, previous occupation, and property ownership. Provided that I control for age, I will be able to identify a pension effect.

\section{Retirement and Living Arrangements}

The utility maximizing veteran evaluates the decision function,

$$
\begin{aligned}
I^{*} & =V_{i}\left(p_{i}, y ; Z\right)-V_{d}\left(p_{d}, y ; Z\right) \\
& =-X^{\prime} \beta+\epsilon
\end{aligned}
$$

where $\epsilon$ is a standard normal error term and $X$ is a vector containing the vector of demographic and socioeconomic variables and of utility shifters $Z$, income $y$, and prices of consumption bundles $p_{i}$ and $p_{d}$ under the independent living and coresidence options, respectively. Although I cannot directly observe the prices that a veteran faces, I can observe characteristics such as marital status, that will determine the price of household goods that the veteran faces. Similarly, although I cannot observe household income, I can observe pension income and proxies for other household income such as past occupation. The value of $I^{*}$ is also not observed, but a discrete headship indicator is observed, given by

$$
I= \begin{cases}0 & \text { if } I^{*}<0 \\ 1 & \text { otherwise }\end{cases}
$$

where 1 represents dependence and 0 independence. The probit equation that is then estimated is

$$
\operatorname{Prob}(I=1)=\operatorname{Prob}\left(\epsilon<X^{\prime} \beta\right)=\boldsymbol{\Phi}\left(X^{\prime} \beta\right)
$$


where $\Phi()$ is a standard normal cumulative distribution function. Because independent living is costly, a veteran with a high pension will have less of a need for the free market goods and household services that he can obtain with coresidence than a veteran with a low pension. Therefore two individuals identical in all characteristics except for pension income may be expected to have different living arrangements. If the individual with the low pension picks the coresidence option while the individual with the high pension does not, then this suggests that that independent living is preferred to coresidence. Only insufficiency of income inhibits it.

The measure of coresidence that I use as a dependent variable is a dummy variable equal to one if the veteran lived in a household which an extended family member headed. This measure is a useful indicator of dependence upon family members. Recall that this measure differs across veterans and non-veterans and that the secular decline in this coresidence indicator has been ongoing since 1880 .

The sample is restricted to noninstitutionalized men who had retired by 1910 . The control variables are derived from the 1900 and 1910 censuses and the pension and surgeons' records. They include number of children, health, age, changes in marital status between 1900 and 1910 , property ownership in 1900 , occupation, literacy, foreign birth, extent of urbanization in county of residence, and geographic region. Foreign birth may determine social norms governing the living arrangements of the elderly. Those who are older and those who are in poor health may find it more costly to maintain their independence. Changes in marital status should matter to the residence decision because the spouse may provide a stream of household services that are not so easily or cheaply replaced by hired help but may be replaced by a daughter or daughterin-law. More importantly, hired help may be a poor substitute for the companionship of family members. The number of children will matter because those with children are more likely to have the option of being dependent upon their families. The lack of living children was widely recognized by contemporary observers as a cause of dependency upon the state or county (e.g. 
Pennsylvania Commission on Old Age Pensions 1919). Property ownership and occupation in 1900 will be proxies for wealth holdings, but property ownership might also reflect any difficulties in liquidating assets. Property ownership is only known for men who were household heads in 1900. Therefore the lack of property is also an indicator of 1900 living arrangements which will be correlated with 1910 living arrangements among those who had retired in 1900 .

The probit results are presented in Table 6. A \$1 increase in monthly pension amount lowered the probability of coresidence by 0.0075 . Evaluated at the pensions means, the elasticity of coresidence with family members with respect to pensions was $-0.77\left(=\frac{18.93}{0.1847}(-0.0075)\right)$. No sharp changes in coresidence at specific pension amounts could be detected. Interactions of pension amount with age dummies, health, and occupation yielded coefficients that were small and insignificant. There were no sharp changes in coresidence at the ages at which Union Army veterans became eligible for a larger pension.

Other important determinants of coresidence were age and changes in marital status. The probability of coresidence was lower at younger ages. Changes in marital status raised the probability of coresidence by the substantial amount of 0.1861 . When pension amount was interacted with the dummy indicator for changes in marital status, the results were inconclusive but suggested that pensions were especially likely to affect the coresidence decisions of widowers. Occupation was an insignificant predictor of coresidence. Not owning property was a significant, positive predictor, but only because those who were not households heads in 1900, and hence owned no property, were more likely to coreside with family members. When the sample is restricted to men who were household heads in 1900 , the coefficient on property ownership still suggests that the wealthier were less likely to reside with a family member who was household head, but the coefficient was not statistically significant. The number of children, whether included linearly or as a spline, was insignificant. However, the sign on the coefficient does suggest that those with no children were less likely to coreside with their extended family as dependent 
Table 6: Probit of Probability of Coresiding with Extended Family Among Retirees, with Coresidence with Extended Family as the Dependent Variable

\begin{tabular}{|l|r|ccc|}
\hline & & \multicolumn{4}{|c|}{361 obs, pseudo $R^{2}=0.27$} \\
\hline \multicolumn{1}{|c|}{ variable } & mean & coef & std err & $\frac{\partial P}{\partial x} c$ \\
\hline \hline dummy=1 if coresiding & 0.20 & $\cdot$ & & \\
constant & & $-8.5004^{\ddagger}$ & 1.3185 & \\
monthly pension & 18.93 & $-0.0384^{\dagger}$ & 0.0198 & -0.0075 \\
age in 1910 & 71.50 & $0.1021^{\ddagger}$ & 0.0186 & 0.0198 \\
number of children & 3.61 & 0.0889 & 0.1041 & 0.0173 \\
number of children squared & 20.91 & -0.0109 & 0.0117 & -0.0021 \\
dummy=1 if & & & & \\
$\quad$ poor health & 0.37 & 0.1345 & 0.1984 & 0.0261 \\
health status unknown & 0.09 & -0.0168 & 0.3142 & -0.0033 \\
1900 occupation & & & & \\
$\quad$ farmer & & - & & \\
$\quad$ professional or proprietor & 0.16 & -0.0373 & 0.2616 & -0.0073 \\
artisan & 0.13 & -0.0388 & 0.2948 & -0.0075 \\
$\quad$ laborer & 0.20 & -0.1982 & 0.2622 & -0.0385 \\
owned no property & 0.29 & $0.7822^{\ddagger}$ & 0.1956 & 0.1520 \\
$\quad$ illiterate & 0.07 & -0.5635 & 0.4227 & -0.1095 \\
foreign-born & 0.10 & -0.6469 & 0.3392 & -0.1257 \\
marital status changed & 0.18 & $0.9296^{\ddagger}$ & 0.2028 & 0.1806 \\
lives in midwest in 1910 & 0.88 & 0.3282 & 0.3093 & 0.0638 \\
100 or more people per square mile & & - & & \\
$\quad$ in county residence in 1910 & 0.20 & 0.3653 & 0.2224 & 0.0710 \\
\hline \hline
\end{tabular}

Note. The omitted dummies are good health and farmer. The symbols $*, \dagger$, and $\ddagger$ indicate that the coefficient is significantly different from 0 at at least the 10,5 , and 1 percent level, respectively. $\frac{\partial P}{\partial x}=\beta \frac{1}{n} \sum \phi\left(x^{\prime} \beta\right)$, where $\phi$ is the standard normal density, and is in probability units. 
relations. Ethnicity remained insignificant even when the foreign-born were divided into ethnic Germans and other foreign-born. Although the coefficient on poor health is insignificant, its sign implies that those in poor health were more likely to pick the coresidence option.

The coefficient on poor health is insignificant, but its sign implies that those in poor health were more likely to pick the coresidence option. The insignificance of the coefficient on poor health suggests that the health variable that I use might be a poor proxy for true health. ${ }^{20}$ If it is indeed a poor proxy, then it is possible that those with higher pensions may be less healthy. When pensions were not awarded on the basis of age, pension amount depended on the veteran's degree of disability. Although pensions were supposed to be awarded regardless of the veteran's financial status, employees of the Pension Bureau may have awarded higher pensions to those living with their families if they regarded coresidence as an indicator of need. Pension amount is therefore potentially endogenous. I therefore use whether or not a recruit applied under the General Law as an instrumental variable.

A probit model with an endogenous explanatory variable can be estimated using twostage conditional maximum likelihood estimation (Rivers and Vuong 1988). This approach yields consistent estimates of pension amount on coresidence under the assumption that the indicator variable for whether the recruit applied under the General Law is a legitimate instrument. The model is composed of a structural equation that is of primary interest and a reduced form equation for the endogenous variable:

$$
\begin{aligned}
I_{i}^{*} & =\alpha P_{i}+Z_{1 i}^{\prime} \beta+u_{i} \\
P_{i} & =\Pi^{\prime} Z_{i}+V_{i} .
\end{aligned}
$$

\footnotetext{
${ }^{20} \mathrm{But}$, note that also in recent data most health variables are not associated with the probability of living alone, with the exception of indicators of difficulty in meal preparation, money management, and telephone use (Wolf 1990).
} 
$I_{i}^{*}$ is not observed, only the dummy variable $I_{i}=1$ if household head and zero otherwise, is. $P_{i}$ is pension amount, $Z_{1 i}$ is a vector of exogenous variables and is a subset of $Z_{i}$, which also contains the instrumental variables excluded from the equation of primary interest. The normally distributed error terms are represented by $u_{i}$ and $V_{i}$. The two-stage conditional maximum likelihood estimation approach can be easily carried out with standard regression and probit programs. In the first stage, pension amount is regressed on the exogenous variables $\left(Z_{1 i}\right)$ and a dummy equal to one if the recruit applied under the General Law. In the second stage, a probit is estimated using pension amount, the exogenous variables, and the residuals from the first step as explanatory variables. Rivers and Vuong (1988) present formulas for the standard errors. ${ }^{21} \mathrm{~A}$ convenient feature of this estimation procedure is that a Hausman test for exogeneity of pension amount is whether the coefficient on the residuals is equal to zero, where the test is estimated using the uncorrected standard errors. In fact, the hypothesis that the coefficient on the residuals is not equal to zero can only be rejected at the 84 percent level of significance, suggesting that endogeneity is not a problem.

Table 7 compares the derivatives of the probit estimates with those from a two-stage conditional maximum likelihood procedure among the men for whom information on the law that they applied under is available. The first stage estimates are also presented. The change in the coefficient on pension amount is small, with the estimated mean effect of a dollar increase in monthly pension amount on the coresidence probability falling from -0.0084 when a probit is estimated to -0.0081 when two-stage conditional maximum likelihood estimation is used. The elasticity of coresidence with respect to pension amount is $-0.80\left(=\frac{18.93}{0.1905}(-0.0081)\right)$.

The elasticities of coresidence with respect to pension income can be used to calculate the impact of a 100 percent reduction in pension amount (from $\$ 18.93$ to 0.01 per month) on

\footnotetext{
${ }^{21}$ When the coefficient on the residuals in the second stage is equal to zero, the standard errors are the usual probit standard errors. There was little difference between the corrected and uncorrected second stage standard errors.
} 
Table 7: Comparison of Derivatives from Probit and from Two Stage Conditional Maximum Likelihood Estimates of Determinants of Coresiding with Extended Family, with Coresidence in 1910 as the Dependent Variable

\begin{tabular}{|c|c|c|c|c|c|c|}
\hline \multirow{3}{*}{$\frac{352 \text { obs }}{\text { Variable }}$} & \multirow{3}{*}{$\begin{array}{l}\text { Probit } \\
\frac{\partial P}{\partial x}\end{array}$} & \multicolumn{5}{|c|}{ 2-stage Conditional Maximum Likelihood } \\
\hline & & \multicolumn{2}{|c|}{$\begin{array}{c}\text { first stage } \\
\text { Adj } R^{2}=0.36\end{array}$} & \multicolumn{3}{|c|}{$\begin{array}{c}\text { second stage } \\
\text { Pseudo } R^{2}=0.27\end{array}$} \\
\hline & & Coef & Std err & Coef & Std err & $\frac{\partial P}{\partial x}$ \\
\hline dummy $=1$ if & & & & & & \\
\hline applied under General Law & & $10.4657^{\ddagger}$ & 0.8234 & & & \\
\hline constant & & -4.3118 & 5.2133 & $-8.5259 \ddagger$ & 1.3543 & \\
\hline monthly pension & -0.0084 & & & $-0.0407^{*}$ & 0.0222 & -0.0081 \\
\hline age $i$ & 0.0204 & $0.3119^{\ddagger}$ & 0.0693 & $0.1029 \ddagger$ & 0.0190 & 0.0203 \\
\hline number of children & 0.0188 & -0.1872 & 0.3980 & 0.0941 & 0.1052 & 0.0186 \\
\hline number of childre & -0.0024 & 0.0350 & 0.0416 & -0.0114 & 0.0119 & -0.0022 \\
\hline dum & & & & & & \\
\hline poor health & 0.0226 & 1.0198 & 0.8504 & 0.1089 & 0.2013 & 0.0215 \\
\hline health status un & -0.0083 & 2.2378 & 1.4675 & -0.0573 & 0.3271 & -0.0113 \\
\hline $\begin{array}{l}1900 \text { occupation } \\
\text { farmer }\end{array}$ & & - & & - & & \\
\hline professional or pro & -0.0082 & -2.1099 & 1.1682 & -0.0400 & 0.2620 & -0.0079 \\
\hline artis & -0.0093 & -1.0035 & 1.4594 & -0.0503 & 0.2958 & -0.0099 \\
\hline laborer & -0.0333 & -1.6120 & 1.1040 & -1.6195 & 1.1044 & -0.0319 \\
\hline ov & 0.1489 & -1.9222 & 0.9018 & 17 & 0.2015 & 0.1506 \\
\hline illite & -0.1138 & $-3.5312^{\ddagger}$ & 1.6051 & -0.5955 & 0.4368 & -0.1177 \\
\hline foreign-born & -0.1308 & -0.2705 & 1.3243 & -0.6602 & 0.3413 & -0.1305 \\
\hline marital status & 0.1832 & $0.8585^{\dagger}$ & 1.0492 & $0.9241^{\ddagger}$ & 0.2049 & 0.1826 \\
\hline lives in midwest in 1910 & 0.0675 & $-3.2096^{\ddagger}$ & 1.2430 & 0.3553 & 0.3174 & 0.0702 \\
\hline 100 or more & & & & & & \\
\hline mile 1910 in county residence & 0.0757 & 1.2071 & 1.0453 & 0.3818 & 0.2237 & 0.0755 \\
\hline residuals first stage & & . & & -0.0051 & 0.0253 & -0.0010 \\
\hline
\end{tabular}

Note. The first stage is a regression of pension amount on the exogenous variables and whether the veteran applied under the General Law. The second stage is a probit with the exogenous variables, pension amount, and the first stage residuals as explanatory variables. The standard errors have been corrected. The symbols $*, \dagger$, and $\ddagger$ indicate that the coefficient is significantly different from 0 at at least the 10 percent, 5 percent, and 1 percent level, respectively. $\frac{\partial P}{\partial x}=\beta \frac{1}{n} \sum \phi\left(x^{\prime} \beta\right)$, where $\phi$ is the standard normal density, and is in probability units. 
average coresidence rates in both the Union Army sample and the random sample of Union Army veterans. This pension reduction would increase the percentage of veterans residing in households headed by a family member from 20 to 36 percent in the Union Army sample and from 14 to 25 percent in the random sample of veterans. Because 32 percent of non-veterans in the random sample were living in an extended household which they did not head, 60 to 100 percent of the difference in coresidence rates between Union Army veterans and non-veterans can therefore be attributed to pensions.

\section{Confederate and Union Veterans}

Variation in pension amount by whether a recruit was able to trace his disabilities to the war has enabled me to separate the impact of pensions from that of age. Another source of variation in the Union Army pension program was disparate treatment by type of veteran. Confederates were ineligible. Information on headship rates among Union Army and Confederate veterans is available from the 1910 Public Use Sample (Preston 1989). One of the questions asked in the 1910 Census was whether the respondent was a veteran, and, if so, whether a Union or Confederate veteran. In 1910 Union pensioners were collecting an average pension of $\$ 171.90$ per year and about 90 percent of all Union veterans were collecting a pension. Although some Confederate states provided pensions, the average pension amount was just $\$ 47.24$ per year and fewer than 30 percent of all Confederate veterans were collecting a pension. ${ }^{22}$ It was mainly the "northernborn," that is men born in a Union state, who fought for the Union, while the "southern-born,"

\footnotetext{
${ }^{22}$ Glasson (1918a; 1918b) gives the number of Civil War veterans on the pension rolls in 1910 . Because of undernumeration of veterans in the 1910 census, the total number of Union Army veterans is estimated from a life table and is from Series Y 957-970 in U.S. Bureau of the Census (1975). Assuming that undernumeration of veterans did not vary among Union and Confederate veterans, the number of Confederate veterans can be calculated from the 1910 public use sample.
} 
that is men born in a Confederate state, fought for the Confederacy. Therefore, the difference in coresidence rates by veteran status in the southern-born sample should reflect a veteran effect, while the difference in coresidence by veteran status in the northern-born sample should reflect both a veteran and a pension effect. In fact, among retirees in the southern-born sample, there was no difference in coresidence by veteran status. ${ }^{23}$ But, among retirees in the northern-born sample, 17 percent of veterans lived in households headed by a family member compared to 30 percent of non-veterans.

Lower coresidence rates among Union compared to Confederate veterans persist even controlling for age, marital status, farm residence, literacy, urbanization, and region of residence (see Table 8). The coefficient on Confederate in the southern-born regression shows that being a Confederate veteran had an insignificant, positive impact on the probability of coresidence. The coefficient on Union veteran in the northern-born regresssion is positive and significant, implying that Union veterans were less likely to coreside with their extended families than northern-born non-veterans. Although it was not possible to control for health, disability levels should be similar across both types of veterans and non-veterans. ${ }^{24}$

The northern-born and southern-born participation functions can be used to estimate whether the difference in coresidence rates between the northern-born and southern-born samples is largely due to differences in observable characteristics or in participation behavior. More formally, let $F^{n}$ be the probability of coresidence with extended family members among the northern-born, $F^{s}$ the probability among the southern-born, and $X^{n}$ and $X^{s}$ the vectors of

\footnotetext{
${ }^{23}$ Thirty-six percent of retired southern-born non-veterans in 1910 were living in households headed by a family member compared to 38 percent of veterans. The difference is not statistically significant.

${ }^{24}$ Although disability levels for Confederate veterans are unavailable, young men in the South were almost three times as likely to die during the Civil War as young Northern men (Vinovskis 1990), suggesting that disability rates were probably higher in the South.
} 
Table 8: Probit of Probability of Coresiding with Extended Family Among White, Native-born, Male Retirees, Northern-born and Southern-born Aged 60-87 in 1910 (from Public Use Sample), with Coresidence as the Dependent Variable

\begin{tabular}{|c|c|c|c|c|c|c|c|c|}
\hline \multirow[b]{2}{*}{ Variable } & \multicolumn{4}{|c|}{$\begin{array}{l}\text { Northern-born } \\
1775 \text { obs, pseudo } R^{2}=0.28\end{array}$} & \multicolumn{4}{|c|}{$\begin{array}{c}\text { Southern-born } \\
385 \text { obs, pseudo } R^{2}=0.32\end{array}$} \\
\hline & Mean & $\begin{array}{c}\text { Para- } \\
\text { meter } \\
\text { Est } \\
\end{array}$ & $\begin{array}{l}\text { Std } \\
\text { Err } \\
\end{array}$ & $\frac{\partial L}{\partial x}$ & Mean & $\begin{array}{c}\text { Para- } \\
\text { meter } \\
\text { Est. }\end{array}$ & $\begin{array}{l}\text { Std } \\
\text { Err } \\
\end{array}$ & $\frac{\partial L}{\partial x} c$ \\
\hline $\begin{array}{l}\text { dummy }=1 \text { if coresiding } \\
\text { intercept } \\
\text { dummy }=1 \text { if }\end{array}$ & 0.26 & $-1.8423^{\ddagger}$ & 0.4111 & & 0.37 & -0.9258 & 0.8334 & \\
\hline $\begin{array}{l}\text { Union veteran } \\
\text { Confederate veteran }\end{array}$ & 0.27 & $-0.2312^{\ddagger}$ & 0.0900 & -0.0201 & 0.37 & 0.2000 & 0.1674 & 0.0193 \\
\hline married & 0.60 & $-1.1607^{\ddagger}$ & 0.0755 & -0.1010 & 0.57 & $-1.0647^{\ddagger}$ & 0.1569 & -0.1029 \\
\hline illiterate & 0.04 & 0.1288 & 0.1724 & 0.0112 & 0.13 & $0.4232^{*}$ & 0.2269 & 0.0409 \\
\hline lives on farm & 0.19 & $1.1972^{\ddagger}$ & 0.0964 & 0.1042 & 0.38 & $1.5358^{\ddagger}$ & 0.1771 & 0.1484 \\
\hline lives & 0.45 & & & & 0.00 & - & & \\
\hline lives in south & 0.11 & $0.2405^{\dagger}$ & 0.1236 & 0.0209 & 0.80 & & & \\
\hline lives in midwest & 0.47 & 0.0548 & 0.0852 & 0.0048 & 0.15 & -0.0939 & 0.2333 & -0.0091 \\
\hline lives in west & 0.08 & -0.0616 & 0.1469 & -0.0054 & 0.05 & 0.0716 & 0.3605 & 0.0069 \\
\hline lives in rural area & 0.61 & $-0.4047^{\ddagger}$ & 0.0863 & -0.0352 & 0.80 & $-0.5437^{\ddagger}$ & 0.2128 & -0.0525 \\
\hline age & 71.54 & $0.0242^{\ddagger}$ & 0.0055 & 0.0021 & 72.01 & 0.0109 & 0.0111 & 0.0011 \\
\hline
\end{tabular}

Note. The sample consists of white, non-institutionalized, native-born men aged 60-87 drawn from the 1910 Census (Ruggles and Sobeck 1995). Rural areas are defined as all unincorporated places and all incorporated places with less than 2,500 residents. The omitted dummy is residence in the east in the northern-born equation and residence in the south in the southern-born equation. The symbols $*$, $\dagger$, and $\ddagger$ indicate that the coefficient is significantly different from 0 at at least the 10 percent, 5 percent and 1 percent level, respectively.

$\frac{\partial P}{\partial x}=\beta \frac{1}{n} \sum \phi\left(x^{\prime} \beta\right)$, where $\phi$ is the standard normal density, and is in probability units. 
northern-born and southern-born characteristics. Then,

$$
F^{n}-F^{s}=\left[F^{n}\left(X^{n}\right)-F^{n}\left(X^{s}\right)\right]+\left[F^{n}\left(X^{s}\right)-F^{s}\left(X^{s}\right)\right]
$$

where the first term is predicted using the northern-born participation equation for both samples and the second term is the residual component due to differences in participation behavior between the northern-born and the southern-born using the southern-born sample. The equation implies that at least 10 percent of the 11 percentage point difference in coresidence rates between the northern-born and southern-born samples can be explained by differences in participation behavior and therefore Union Army pensions. ${ }^{25}$

\section{Implications}

Union Army pensions, as I have shown, exerted a sizable, negative impact on the coresidence rates of the retired. The elasticity of coresidence with family members with respect to Union Army pensions was -0.77 . Union Army pensions could thus explain 60 to 100 percent of the difference in coresidence rates between retired Union Army veterans and non-veterans and at least 10 percent of the difference in coresidence rates between native-born men born in the north and those born in the south. My findings suggest that it is not just the aged of today who prefer to live alone (University of Michigan. Survey Research Center. 1962), but the aged of the past as well. Increases in income have always been associated with an increased demand for the privacy and autonomy provided by separate living arrangements.

Estimates of the impact of Union Army pensions on coresidence rates can be used to

\footnotetext{
${ }^{25}$ The absolute value of the actual difference in coresidence rates is 10.2 . The first term in the first equation is -9.19 and the second term is -1.03 .
} 
calculate the effect of a secular increase in income on the secular decline in coresidence with family members among the retired. Assuming that the retirement assets of the elderly kept pace with per capita GNP, retirement assets should have increased by 32 percent between 1910 and 1940. The estimated elasticity of coresidence with family members with respect to Union Army pensions implies that 86 percent of the decline in coresidence rates between 1910 and 1940 can be explained by increases in income. Rising incomes have therefore been the most important factor enabling the elderly to live alone. ${ }^{26}$

Extrapolations of the regression results to the present yield nonsensical results, suggesting that elasticities calculated from 1910 data cannot be applied to the present. In fact, Börsch-Supan et al. (1992) find that increasing the income of the elderly does not raise the probability of their living alone relative to the probability of their living with their children. Schwartz, Danziger, and Smolensky (1984) also find that income has a small impact on the propensity of the elderly to live alone (cf. Michael, Fuchs, and Scott 1980). The elasticity appears to have fallen.

One factor that may have served to lower the elasticity is increases in the value of independent living. If independent living is now attractive and inexpensive enough then a large increase in income will not lead to a large increase in retirement coresidence rates. Conversely, a large decrease in income will not lead to a large decrease in coresidence rates. The appearance of single portion food products, the growth of housing for single individuals and of retirement communities, and the rise in private and state social support services have lowered the price of the elderly living alone. A leisurely retirement lifestyle, filled with recreational activities including mass tourism, low impact sports such as golf, and inexpensive entertainments such as television watching, is often made possible by resettlement to a community with a better climate or other

\footnotetext{
${ }^{26}$ The regression estimates suggest that improvements in the health of the elderly or falling fertility are unlikely explanations for the remaining 14 percent decline in coresidence rates, but that a decreasing probability of widowhood for elderly men may be a factor.
} 
environmental amenities or to one with a low cost of living. Such a community is not necessarily one in which children or relatives reside, but is one with greater recreational opportunities. As recreational opportunities have expanded, independent living may have become more attractive. The increasing attractiveness of independent living may in turn have increased the attractiveness of retirement. The elasticity of labor force non-participation with respect to income is now lower than it was in 1900 (Costa 1995), implying that the retirement decision of older men is simply no longer as responsive to changes in income. One explanation is that retirement is now much more attractive. The elderly can now live independently, spending their time in recreational pursuits.

\section{References}

[1] Börsch-Supan, V. Hajivassiliou, J. Kotlikoff, and J.N. Morris. 1992. "Health, Children, and Elderly Living Arrangements." In David A. Wise (Ed.), Topics in the Economics of Aging. Chicago: The University of Chicago Press: 79-104.

[2] Costa, Dora L. 1993. "Height, Weight, Wartime Stress, and Older Age Mortality: Evidence from the Union Army Records." Explorations in Economic History. 30: 424-449.

[3] Costa, Dora L. 1995. "Pensions and Retirement: Evidence from Union Army Veterans." Quarterly Journal of Economics. 110(May): 297-320.

[4] Epstein, Abraham. 1928. The Challenge of the Aged. New York: The Vanguard Press.

[5] Fogel, Robert W., Michael Haines, Clayne L. Pope, Irwin H. Rosenberg, Nevin S. Scrimshaw, James Trussell, Larry T. Wimmer. 1991. Early Indicators of Later Work Levels, Disease, and Death. Grant Proposal Submitted to N.I.H.

[6] Glasson, William H. 1918a. Federal Military Pensions in the United States. New York: Oxford University Press.

[7] Glasson, William H. 1918b. "The South's Pension and Relief Provisions for Soldiers of the Confederacy." Publications of the North Carolina Historical Commission. Bulletin No. 23. Raleigh, NC: 61-71.

[8] Gratton, Brian and Frances M. Rotondo. 1991. "Industrialization, the Family Economy, and the Economic Status of the American Elderly." Social Science History. 15(3): 337-362. 
[9] Longino, Charles F. Jr. 1990. "Geographical Distribution and Migration." In R.H. Binstock and Linda K. George (Eds.), Handbook of Aging and the Social Sciences. San Diego, CA: Academic Press, Inc.

[10] Michael, Robert T., Victor R. Fuchs, and Sharon R. Scott. 1980. "Changes in the Propensity to Live Alone, 1950-1976." Demography. 17: 39-56.

[11] Pennsylvania Commission on Old Age Pensions. 1919. Report of the Pennsylvania Commission on Old Age Pensions. Harrisburg, PA.

[12] Rivers, Douglas and Quang H. Vuong. 1988. "Limited Information Estimators and Exogeneity Tests for Simultaneous Probit Models," Journal of Econometrics. 39: 347-366.

[13] Ruggles, Steven. 1987. Prolonged Connections: The Rise of the Family in Nineteenth Century England and America. Madison, WI: University of Wisconsin Press.

[14] Ruggles, Steven and Matthew Sobek. 1995. Integrated Public Use Microdata Series, IPUMS95 Version 1.0. Social History Research Laboratory. Department of History. University of Minnesota.

[15] Schorr, Alvin L. 1960. Filial Responsibility in the Modern American Family: An Evaluation of Current Practice of Filial Responsibility in the United States and the Relationship to it of Social Security Programs. Washington, DC: U. S. Dept. of Health, Education, and Welfare, Social Security Administration, Division of Program Research.

[16] Schwartz, Saul, Sheldon Danziger, and Eugene Smolensky. 1984. "The Choice of Living Arrangements by the Elderly." In Henry J. Aaron and Gary Burtless (Eds.), Retirement and Economic Behavior, Washington DC: The Brookings Institution: 229-253.

[17] Smith, Daniel Scott. 1979. "Life Course, Norms, and the Family System of Older American in 1900." Journal of Family History. 4: 285-298.

[18] University of Michigan. Survey Research Center. 1962. Income and Welfare in the United States, a study [by] James N. Morgan [and others] with the assistance of Norma Meyers and Barbara Baldwin. New York: McGraw-Hill.

[19] U.S. Bureau of the Census. 1975. Historical Statistics of the United States, Colonial Times to 1970. Washington: GPO.

[20] U.S. Bureau of the Census. 1993. Statistical Abstract of the United States: 1993. Washington, DC: Government Printing Office.

[21] U.S. Bureau of Pensions. 1910. Report of the Commissioner of Pensions. Washington DC: Government Printing Office.

[22] Waaler, H.T. 1984. Height, Weight, and Mortality. The Norwegian Experience. Acta Medica Scandinavica [Suppl.]. 679: 1-56. 
[23] Wolf, Douglas A. 1990. "Household patterns of older women: Some international comparisons." Research on Aging. 12(4): 463-486.

[24] Wolf, Douglas A. 1994. "The Elderly and Their Kin: Patterns of Availability and Access." In L.G. Martin and S.A. Preston (Eds.), Demography of Aging. Washington, DC: National Academy Press: 146-194.

[25] Vinovskis, Maris A. 1990. "Have Social Historians Lost the Civil War? Some Preliminary Demographic Speculations." In M. Vinovkis (Ed.), Toward a Social History of the American Civil War. Cambridge: Cambridge University Press: 1-30. 